\title{
ANALYSIS OF FEEDING PATTERN AND HEALTH PRACTICES IN CHILD 6-24 MONTHS NUTRITIONAL STATUS IN MAKASSAR, BUGIS AND TORAJA TRIBES
}

\section{(Analisis pola makan dan praktik kesehatan serta status gizi anak 6-24 bulan pada suku Makassar, Bugis dan Toraja)}

\author{
Armenia Eka Putriana $^{1^{*}}$, Drajat Martianto ${ }^{2}$, Hadi Riyadi $^{3}$ \\ ${ }^{1}$ Departemen Gizi Masyarakat, Fakultas Ekologi Manusia (FEMA), Institut Pertanian Bogor, Bogor, Indonesia. \\ Email: armenia@stikeswnpalu.ac.id \\ ${ }^{2}$ Departemen Gizi Masyarakat, Fakultas Ekologi Manusia (FEMA), Institut Pertanian Bogor, Bogor, Indonesia. \\ Email: drajat_martianto@yahoo.com \\ ${ }^{3}$ Departemen Gizi Masyarakat, Fakultas Ekologi Manusia (FEMA), Institut Pertanian Bogor, Bogor, Indonesia. \\ Email: hadiriyadi@yahoo.com
}

\begin{abstract}
The cultural practices of eating in the Makassar, Bugis and Toraja tribes have a variety of unique characteristics based on their respective beliefs. Objective of this study was to analyze the practice of feeding pattern and health practices in child under two years nutritional status in Makassar, Bugis and Toraja tribes. The study using a cross-sectional study design. Total 360 child under two years were divided into 3 tribes: 120 in Makassar tribes, 120 in Bugis tribes and 120 in Toraja tribes. The results showed that there were significant differences in parenting feeding pattern on cultural. The parenting feeding pattern style applied by child under two years mothers is mostly in the Toraja tribe (OR: 1,6), less than the Makassar and Bugis tribes. Health parenting in Bugis tribe $($ OR: 8,1) is better than the Toraja and Makassar tribes. In conclusion, the highest percentage of parenting feeding pattern styles in the less category is Makassar tribe and the highest percentage of health care patterns in the good category is Toraja tribe.
\end{abstract}

Keywords: Cultural practices, feeding practices, health practices, nutritional status

\begin{abstract}
ABSTRAK
Praktek terhadap budaya makan di suku Makassar, Bugis dan suku Toraja memiliki berbagai karakteristik unik berdasarkan keyakinan masing-masing. Tujuan penelitian untuk menganalisis praktik pola makan dan praktik kesehatan serta analisis status gizi pada anak di bawah dua tahun pada suku Makassar, Bugis dan suku Toraja. Penelitian menggunakan desain potong lintang. Total sampel yaitu 360 anak di bawah dua tahun yang berasal dari 3 suku: 120 di suku Makassar, 120 di suku Bugis dan 120 di suku Toraja. Hasil penelitian
\end{abstract}

menunjukkan terdapat perbedaan signifikan terhadap pola makan orang tua pada budaya. Model pola asuh makan yang diterapkan kepada anak dibawah dua tahun oleh ibu sebagian besar berada di suku Toraja kurang baik (OR: 1,6), dibandingkan dari suku Makassar dan Bugis. Pelayanan kesehatan oleh orang tua kepada anakanak mereka di suku Bugis (OR: 8,1) lebih baik dari pada suku Toraja dan Makassar. Kesimpulan, persentase tertinggi pola pola asuh makan dalam kategori kurang adalah suku Makassar dan persentase tertinggi pola perawatan kesehatan dalam kategori baik adalah suku Toraja.

Kata kunci: Praktik budaya, praktik pols makan, praktik kesehatan, status gizi

\section{INTRODUCTION}

A total of 14 provinces are in the heavy category and as many as 15 provinces are in the serious category, these 15 provinces are Papua, Maluku, South Sulawesi, North Maluku, Central Sulawesi, Central Kalimantan, Aceh, North Sumatra, Southeast Sulawesi, Lampung, South Kalimantan, West Papua, West Nusa Tenggara, West Sulawesi and East Nusa Tenggara. ${ }^{1}$ Stunting in toddlers needs special attention because it can hamper children's physical and mental development. Stunting is associated with an increased risk of morbidity and death and stunted growth in motor and mental abilities. ${ }^{2}$

${ }^{*}$ Corresponding author: armenia@stikeswnpalu.ac.id 
The period between pregnancy or fetus until the first two years of a child's life is a critical period due to the highest nutritional needs in this group even though this group is most prone to obtaining wrong parenting and health. Inadequate access to health services and inappropriate feeding patterns. Through the phenomenon and development of the category of the meal will be dealing and with regard to the categories of culture, categories of social life, religion, economic life, science, technology, and so on. ${ }^{3,4}$

Feeding pattern is a term used to describe the habits and behaviors regarding food and eating, e.g. the way of eating, frequency of meals, feeding patterns, beliefs about food (dietary restrictions), the distribution of food within the family, receipt of food (for example like or dislike) and how the selection of food that will be eaten. ${ }^{3,5}$

The behavior of a person's health influenced by three factors namely knowledge, attitude, education, public trust, social, cultural and economic levels, furthermore, possible factors that include the availability of facilities and infrastructure or health facilities for the community example clean water, waste disposal, place of disposal of the stool, the availability of nutritious foods and so on, then the last, supporting factors which include attitudes and health behavior. ${ }^{3}$

Fulfillment of nutrition in children under five years of age is a factor to consider in maintaining health, because they are vulnerable developmental period of nutrition. ${ }^{6}$ The nutritional status of older toddlers one influenced by the socio-economic condition factor, among others, the education of their mother, the mother's work, the number of children, knowledge and parenting mothers as well as the economic conditions of the elderly as a whole. ${ }^{7}$

When the society moved into areas with cultural value differences, adapting to the new community was started. This process is called acculturation. Culture-based eating habits often becomes one of the last practice was changed by the community through acculturation. Eating is usually done in the privacy of the house, hidden from the observations of the majority of members of the public. ${ }^{8}$ This research is expected to be able to enrich knowledge about the relationship between food consumption patterns, parenting and healthy living habits in children under two years with the nutritional status of under two children from families with different cultural backgrounds in preventing stunting or other nutritional problems.

\section{METHOD}

The design quantitative of this research is a cross sectional study. This is place in Gowa District (Makassar), Wajo District (Bugis) and district of Tana Toraja (Toraja) conducted in July-September 2016. The subject amounts to 120 on child under two years each tribes. Total subject to Makassar, Bugis and Toraja tribe is 360 child under two years.

Table 1. Total subject based on tribes, districts, sub-districts and villages

\begin{tabular}{llll}
\hline Tribes & Makassar & Bugis & Toraja \\
\hline Districts & Gowa & Wajo & Toraja \\
\hline Sub-districts & Pallangga & Sa'bang & Makale \\
\hline Villages & 1. Mangalli & 1. Wage & 1. Lamunan \\
& 2. Je'ne Tallasa & 2. Pasaka & 2. Limbong Burake \\
& 3. Parangma'lengu & 3. Sompe & 3. Bombongan \\
& 4. Je'ne Cinnong & 4. Mallusesalo & 4. Kampung Baru \\
& 5. Borongtalla & 5. Wallanae & 5. Tampa \\
& 6. Karampuang & 6. Ujung Pelo & \\
\hline $\begin{array}{l}\text { Total Subject } \\
\text { (child under }\end{array}$ & 150 childs & 7. Talo Tenreng & \\
two years) & & & 150 childs \\
\hline
\end{tabular}


This research using primary and secondary data. The supporting data in the community public health center. Primary data include household characteristics, characteristics of the child under two years, knowledge of nutrition, food consumption patterns, parenting health and nutritional status of child under two years. Anthropometry data include weight and height is obtained by direct measurement by the enumerator. Food consumption data obtained with the method of Food Frequencies Questionnaire (FFQ) household food consumption for the past month.

Processing and analysis of data using Microsoft Office programs Excel and SPSS are descriptive. The bivariat analysis used was chisquare test and Fisher (chi-square test alternative). Multivariate analysis used is logistic regression. Logistic regression analysis was performed using the method of Backward: Wald with CI 95\% level of confidence. ${ }^{9}$ Parenting packed using data consumption based on parenting methods can be obtained from the interview using the FFQ. From the results of the interview can be seen child under two years feeding. Family members are most often determine the food child under two years is the mother. Parenting health is one way to know is to do a child growth weighing weight every month. It has been recommended that the activities need to be performed in child considering Pos Integrated Services exist in each region (district). In addition to weighing the child through Pos Integrated Services activities, parents also obtain other information about health.

\section{RESULT AND DISCUSSION}

\section{Feeding Pattern Practices}

Preliminary studies about food more highlight the problem of feeding pattern as a form a highly patterned behavior related to culture, which includes also the trust and abstinence of feeding that developed in a group of community and also with regard to environmental factors as the source of acquisition of the main foodstuffs..$^{10}$ Nutriment is a concept of Biochemistry, a substance that is able to maintain and preserve the health of the organism, while swallowing food is a cultural concept, something eaten with the passage of the culture. This means food as a cultural concept will have a broader meaning than the food in the concept of nutriment. Food with cultural endorsement means it will be concerned with belief, dietary restrictions, rules, technology, etc. that grow and develop in a group of people, thus becoming the feeding pattern that became the hallmark of a bunch of communities and the difference with other community groups. ${ }^{11}$

The results in Makassar tribe obtained show that $62,5 \%$ of mothers are still lacking in applying the correct parenting to their children. As many as $30,8 \%$ of mothers have parenting which is categorized as sufficient. Meanwhile, there are only less than $10 \%$ of mothers who have a good care pattern. More than $50 \%$ of the Buginese tribe mothers have sufficient parenting. However, $40,8 \%$ of mothers are still classified as lacking in their parenting, while the remaining $6,7 \%$ of mothers are in the good category in applying parenting to their baduta. Picture of the level of parenting eating Baduta in the Toraja tribe The results obtained show that of the three categories, $51,7 \%$ of mothers with a sufficient category dominate the existing percentage. Meanwhile, mothers in the category of eating care were lacking around $39,2 \%$, and only $9,2 \%$ of mothers had a good category for parenting for their child.

Traditional society consists of a group of people who have a relationship that is still very strong especially in terms of mastery of the region, culture, and identity. A major feature of life in traditional societies, among others, have a language that is unique and different, have invaluable knowledge and resource management practices related hereditary nature are ongoing, as well as have the rules certain particularly in terms of traditional land use. For indigenous peoples, land or ancestral lands have a fundamental role for collective survival, both physically and culturally. Indigenous people generally do daily activities based on traditional values, vision, needs, and priorities. $^{12}$ 
Table 1. Feeding pattern practice of Makassar, Bugis and Toraja tribes

\begin{tabular}{|c|c|}
\hline Tribe & Practices of Feeding Pattern \\
\hline Makassar & $\begin{array}{l}\text { - Should not eat in front of the door. } \\
\text { - The husband should not kill the animals. }\end{array}$ \\
\hline Bugis & $\begin{array}{l}\text { - Abstinence of eating squid on while pregnant } \\
\text { - Abstinence of eating fish } \\
\text { - Abstinence of eating shrimp }\end{array}$ \\
\hline Toraja & $\begin{array}{l}\text { - Provide coffee at baduta at birth. } \\
\text { - Provide processed eel. } \\
\text { - Provide processed quail eggs. }\end{array}$ \\
\hline
\end{tabular}

Table 1 shows that at the Makassar tribe tend in practice to eat and the restrictions made by the husband when his wife was pregnant. In this study, child uder two years on the Makassar tribe have no dietary restrictions or any kind of food taboos. Because older people child under two years on the Makassar tribe is already included in the scope of the modern cultural influences and so was not too be implemented along with the knowledge owned by the parents of child under two years. It should be also noted that any given food sometimes instant meals too fast food for reasons practical and have arranged the busyness if on weekdays. One of the roles of parents responsible for the fulfillment of the nutrients on the Cubs, the desire of parents to meet the needs of his son's nutritional substances often aspects influenced the practice of feeding the less precise. This gives rise to differing practices in conducting the feeding in children. Feeding practices that are less precise, among others, always fulfilling the will of the child to consume foods that he wanted. ${ }^{12}$

Mother's in the Bugis tribe have cultural practices tend to eat more at the time pregnant. Some foods considered taboo. As in the study found that most expectant mothers abstinence of eating squid. On the grounds that they believe if eating squid while pregnant baby it contains will have skin that is black as ink, owned by squid. Squid is an animal of Phyllum Mollusks are much favored because it contains high nutritional value. ${ }^{13}$ Note that this squid ink contains details of melanin or pigment black. Melanin is a natural melanoprotein containing 10-15\% protein, thus becoming one of a good source of protein because it is just as good as protein content in the flesh. ${ }^{14}$

Then the fish consumed due to abstinence largely mum on the Bugis tribe believe that would cause fishy smell on babies when born. It is known that fish is one of the foodstuffs that contain a variety of substances, in addition to the price generally cheaper, fish protein absorption is higher compared to other animal products such as beef and chicken, as fish flesh have protein fibres shorter than fibers of protein as beef or chicken. Kind is very diverse and has a number of advantages, among which are contains omega 3 and omega 6 , and completeness of the amino acid composition. ${ }^{15}$ Fish is a food of excellent quality of its nutrition value, because it contains more or less 18 grams of protein for every 100 grams of fresh fish. While fish dried can be up to 40 grams of protein in 100 grams of dried fish. In General, fish and marine fish in particular is a food which is rich in iodine. These substances needed by the body to form the hormone thyroxine. The content of iodine contained in fish reaching 83 microgram/100 grams of fish. While the meat only contains 5 micrograms/100 grams. Thus a high sea fish consumption can prevent the disease due to lack of iodine consumption (GAKY). In addition to protein, fish that are rich in minerals such as calcium, phospor required for bone formation, as well as iron is required for the formation of hemoglobin in blood. While the fat content of fish at $70 \%$ consists of unsaturated fatty acids, while the meat is mostly composed of saturated fatty acids. $^{16}$ 
And most also believed that if the mother consumes shrimp babies conceived will have poor posture such as shrimp (hunchback). Abstinence of eating shrimp in line with research that total abstinence from eating the leaves of the kelor, prawns and crayfish can still be found on indigenous peoples To Lotang. ${ }^{17}$ Research on communities of Jeneponto where food abstinence of the shrimp-like animal was banned because it causes the baby back and forth labor means that society believe that by eating the shrimp will complicate the process of childbirth. ${ }^{18}$ Abstinence of eating shrimp there are throwing away food wrappers in relation to trust totem closed, throw away Trash because the name of the type of fish it was worn through the Windows, nailing something, as the name of a Duke in closing the water flow/nest holes, Wirasaba, as referred to in the script binds to something, and the loop according to Banyumas. ${ }^{19}$

At the shrimp contained active compounds that are beneficial to humans. The active compounds have an important role for health, growth and development of the human body. The active compounds like fatty acids (omega- 3 and omega-6) on the shrimp and fish are beneficial to the development of children's brains, for baby, for pregnant women. ${ }^{20}$ The shrimp contained active compounds that can be found is Chitosan, minerals, lipids, carotenoid protein has a high economic value. ${ }^{21}$ In connection with active compounds suggests that that the shrimp is one of the highest sources of active compounds to the amino acids. ${ }^{22}$ While Regard to the composition of shrimp consists of nutrients, essential amino acids, fat composition, macro minerals, and micro minerals. ${ }^{23}$

Most of the mothers at the Toraja have a habit or a certain tradition in terms of eating practices such as giving coffee of her baby when baby is at birth so when assuming the baby fever doesn't occur step (seizures), gives the tail the eel with the assumption in order for his son to be a child who is agile and don't give a fish on baby because most of the mothers believed that if her son ate the fish so the child will experience intestinal worms. It is understood the culture that still applied by the majority of mothers in the Toraja. But education can affect a person's learning process, the higher education of a person will be easier in receiving the information. The more information enter the more knowledge gained includes information about health. The higher education of a person then the knowledge that someone will be higher. But someone who is educated not necessarily knowledgeable low also.

\section{Cultural Practices Of Health}

Basically very individual has the desire to be in a healthy and normal conditions, so if it feels threatened or compromised health conditions caused by disease, then they are driven to do an attempt to restore and improve the condition of their health.

Table 2. Health culture practices at Makassar, Bugis and Toraja tribe

\begin{tabular}{|c|c|}
\hline Tribe & Health Culture Practices \\
\hline Makassar & $\begin{array}{l}\text { - Visit the Posyandu on schedule regularly } \\
\text { - Do the weighing on child under two years on schedule. } \\
\text { - Perform periodic immunization } \\
\text { - If baby is sick, soon brought to Posyandu to get care } \\
\text { - Pregnant mother's health checked at Posyandu content } \\
\text { - } \text { Receive and consume the PMT. } \\
\text { - The husband should not kill animals } \\
\text { - Should not eat in front of the door }\end{array}$ \\
\hline Bugis & $\begin{array}{l}\text { - Caring for a baby without a nanny } \\
\text { - Follow the whims of children if not want to eat }\end{array}$ \\
\hline Toraja & - Regular checked into the Posyandu \\
\hline
\end{tabular}


The understanding of the participants regarding the incidence of certain diseases caused due to the breach of pemali. Understanding as well as the beliefs are formed based on personal experience, as well as the information they get from the immediate environment, and then encourage them to take actions aimed at maintaining their health conditions especially for prevention. ${ }^{24}$

Table 2 explains that overall most of the mothers at the Makassar, Bugis, and Toraja Tribe do health practice well. In culture on health practices, was not fully influenced by culture. There are still a few that are done in the everyday health practices. One of them is on the Makassar Tribe. A small part still believe that when the mother is pregnant, the husband should not be killing animals and eating in front of the door. With an explanation that when a husband killing animals so the baby would be born by the mother will be compromised his health, especially in the form of the physical form of the baby (disabled). Later in the practice of culture that the husband should not eat in front of the door, it was considered that would deter or fortune there are evil spirits who entered so that the impact on the body condition in this case healthcare.

Illustration of level of health care pattern for child in Makassar tribe. The results obtained showed that of the three categories, $58,3 \%$ of mothers with a good parenting category dominated the percentage of the total. Meanwhile, mothers in the category of health care are sufficient about $34,2 \%$, and only $7,5 \%$ of mothers have a category lacking health care for their baduta. Baduta health care patterns in the Bugis tribe, the results obtained show that of the three categories, more than $80 \%$ of mothers with good health care parcels dominate the percentage. Meanwhile, mothers in the category of adequate health care are around $15,8 \%$, and only $1,7 \%$ of mothers have a lack of health care for their baduta. Illustration of the level of health care pattern of the baduta in the Toraja tribe, the results obtained show that from the three categories, more than 63 child get good parenting from mothers. Meanwhile, there were 54 baduta in the category of health care that were enough, and there were 3 child in the category of lacking health care for their child.
The process of globalization will make a number of people to get back on their ethnicity, i.e. a process to find an identity. Bugis and Makassar ethnic are two among the four major ethnicities residing in South Sulawesi. In fact, culture and Outlook on life in General, Bugis equal and harmonious with culture and view of life the people of Makassar. Therefore discusses the culture of Bugis hard released with a discussion of the culture of Makassar. ${ }^{25}$ This is in line with the views that says that in the system of family or kinship in human life human Bugis and Makassar, it can be said there is almost no difference. It further expressed that both ethnic groups (the Bugis and makassar) in fact represents a cultural unit. Therefore, what is happening in the world of man also applies Bugis, Makassar on humans. ${ }^{26}$

Practice use and influence of pemali quite thick felt on society in Toraja Regency North of the South Sulawesi province. Toraja society beliefs against the pemali embodied in the behavior of the obedient and does not violate the pemali believed to be able to prevent them from consequences in the form of the disease, crops, or other adverse events. The views of the public about the pemali is a teaching that is derived or handed down by the ancestors, contain ethical rules and rites and symbols connects humans typically with factual, either with the order of the divine, as well as with fellow human beings and nature. It is this belief that form the view of life and became the Toraja society culture inherent with so strong. ${ }^{23}$

Although many of the Toraja society that says pemali not apply again as in the past, because now people have had a belief in God or religion, but until now without their even knowing they do it anyway. One of the real evidence of the application of pemali in everyday life was shown by participants, namely by not doing or consuming certain types of foods that are considered taboos. The Act is based on a belief that becomes their reference to date, that adherence to the pemali particularly if they do not consume certain types of meats that are considered pemali if mixed together, can prevent they are of the type of specific disease and misfortune of others. The pattern of life that continues until today, and become a continuous 
process from generation to generation because the participant pass it on to their sons and grandsons. ${ }^{23}$

Basically every individual has the desire to be in a healthy and normal conditions, so if it feels threatened or compromised health conditions caused by disease, then they are driven to do an attempt to restore and improve the condition of their health. The understanding of the participants regarding the incidence of certain diseases caused due to the breach of pemali. Understanding as well as the beliefs are formed based on personal experience, as well as the information they get from the immediate environment, and then encourage them to take actions aimed at maintaining their health conditions especially for prevention. ${ }^{23}$

Nutritional status is someone who can be assessed to find out if someone is normal or problematic (nutrition). The wrong nutrition is health disorders caused by deficiency or excess or imbalance and nutrients necessary for growth, intelligence, and activities or productivity. ${ }^{1}$ According to Riyadi (2001) ${ }^{27}$, nutritional status describes the Status of health of a person's body or a group of people caused by the ingestion, absorption of nutrients, and use of food. By assessing the nutritional status of a person or group of people, then it can be known to be good or bad status of its nutrition value. Nutritional factors affecting nutritional status directly i.e. food consumption and health circumstances. Kids Toddler is the most frequent age group suffer from malnutrition and disease-prone, because the assumption is currently transitioning from baby food to adult food, kids toddlers have not been able to take care of itself, including food, and usually already have toddlers or younger his mother working so that his attention has been reduced. ${ }^{28}$ The effects of poor nutrition on mental development and the brain depending on the severity, duration and timing of the growth of the brain itself. nutritional problems are very complex and have a very broad dimension, not only about the health aspects but also includes issues of social, economic, cultural, educational, education, environment and behavior. $^{27}$

Table 3. Proportion of nutritional status of child at Makassar, Bugis and Toraja tribe

\begin{tabular}{lcccccc}
\hline \multirow{2}{*}{ Tribes } & \multicolumn{2}{c}{ Stunting } & \multicolumn{2}{c}{ Normal } & \multicolumn{2}{c}{ Total } \\
\cline { 2 - 7 } \multicolumn{1}{c}{$\mathrm{n}$} & $\% 3$ & $\mathrm{n}$ & $\%$ & $\mathrm{n}$ & $\%$ \\
\hline Makassar & 63 & 52,5 & 57 & 47,5 & 120 & 100 \\
Bugis & 103 & 85,8 & 17 & 14,1 & 120 & 100 \\
Toraja & 28 & 23,3 & 92 & 76,6 & 120 & 100 \\
\hline Total & 194 & 53,9 & 166 & 46,1 & 360 & 100 \\
\hline
\end{tabular}

Based on the results of the study are listed in Table 3 above found that amounted to $85,8 \%$ child under two years is stunting with a total of 103 child under two years at Bugis. Stunting is a chronic nutritional problem that arise as a result of the state of undernourishment that accumulate in quite a long time. Caregiving is a factor that is closely associated with the growth and development of children under five years. More specifically, nutritional deficiency can cause growth retardation Agency, more importantly delays brain development and may also decline or the low durability of the body against infectious diseases. ${ }^{4,29}$
Height is the result of cumulative growth since birth. Suggested that the height is Anthropometry growth state that describe the skeletal. In normal circumstances the height grow along with increasing age. Index TB/U in addition to providing an overview of the nutritional status of the past, is also more closely related to socioeconomic status. Suggested that the height index according to age more describe the nutritional status of the past. Based on the criteria of WHO qualifies as a public health problem, is very high when the prevalence of shorter (stunting) above $40 \%$, then public health problem in this research area are categorized as very high. ${ }^{30}$ 


\section{CONCLUSION}

Many factors affect the nutritional status of the child, both factors of direct or indirect factors. Culture is one of the factors that influence is not direct nutritional status of the child. Culture is one of the factors that influence the attitude of mothers in her pregnancy, the process of childbirth, as well as in parenting a child. The existence of differences in the level of knowledge on the various tribes led to the diversity in parenting. The influence of the environment is still very instrumental and nurturing mother in compliance also greatly influences the quality of children's health. So expect the existence of advanced research, among other things, father and parenting support psychosocial monitoring growing hibiscus baduta, especially the problem of stunting.

\section{REFERENCES}

1. Indonesian Ministry of Health. Basic Health Research Results Report Indonesia Years 2013. Jakarta, Indonesia; 2013.

2. Purwandini K, Kartasurya M. Effect of sprinkle micronutrient administration on motor development of Stunting children aged 12-36 months. Journal of Nutrition College. 2013;2(1):147-163.

3. Nadiyah, Briawan D, Martianto D. Risk Factors of Stunting among 0-23 Month Old Children in Bali Province, West Java and East Nusa Tenggara. Jurnal Gizi dan Pangan. 2014;9(2):125-132. doi:https://doi.org/10.25182/jgp.2014.9.2. $\% 25 \mathrm{p}$.

4. AL-Rahmad AH, Miko A, Hadi A. Study of stunting among children under five in terms of exclusive breastfeeding, complementary feeding, immunization status and characteristics of families in Banda Aceh. Jurnal Kesehatan Ilmiah Nasuwakes. 2013;6(2):169-184.

5. Miko A, Pratiwi M. Relationship to eating pattern and physical activity with obesity in Health Polytechnic students Ministry of Health in Aceh. AcTion: Aceh Nutrition Journal. 2017;2(1):1-5. doi:http://dx.doi.org/10.30867/action.v2i1 .29 .

6. Fidiantoro N. Model of The Determination of Nutritional Status in Clinics. Jurnal Sarjana Teknik Informatika. 2013;1(1):367-372.

7. Putri RF, Sulastri D, Lestari Y. Factors associated with childhood nutritional status in working area clinics Nanggalo, Padang. Jurnal Kesehatan Andalas. 2015;4(1):254-261.

doi:https://doi.org/10.25077/jka.v4.i1.p\% 25p.2015.

8. Kittler PG, Sucher KP, Nelms M. Food and Culture. California (USA): Cengage Learning; 2011.

9. Dahlan S. Statistics for Medical and Health. Issue 5. Jakarta: Salemba Medika; 2011

10. Nurti Y. The Study of Food in The Perspective of Anthropology. Jurnal Antropologi: Isu-isu Sosial Budaya. 19(1): 1-10. Jurnal Antropologi: Isu-isu Sosial Budaya. 2017;19(1):1-10.

11. Foster A. Health Anthropology. Jakarta: UI-Press; 1986.

12. UNICEF. United Nations Declaration on the Rights of Indigenous Peoples for Indigenous Adolescents. New York (US); 2013.

13. Nurjanah. Physical and Chemical Characteristics of Flour Shell Local Gravestone (Pylsbrioconchs exilis). Jurnal Pengolahan Hasil Perikanan Indonesia. 2011;12(1):12-19.

14. Astawan M. Healthy Animal Dishes. Jakarta: Penebar Swadaya Grup; 2008.

15. Pandit IGS, Suryadhi NT, Arka IB, Adiputra N. Influence of Weeding and Storage Temperatures Against Chemical Purity, Quality And Organoleptic Tuna (Auxis tharzard, 1.). 2012.

16. Kartasapoetra. Nutrition (Correlation of Nutrition, Health and Productivity of Work). Jakarta: Rineka Cipta; 2010.

17. Burhan A, Citrakesumasari, Najamuddin U. Eat Culture of Pregnant and Breastfeeding Women on Indigenous Peoples To Lotang, Amparita Village, Tellu Limpoe Subdistrict, Sidenreng 
Rappang District. Makassar; 2014. http://103.195.142.17/bitstream/handle/12 3456789/11335/AZWAR BURHAN K21110293.pdf?sequence $=1$.

18. Priyadi S. The Symbolic Meaning of Abstinence on Pregnant Women in Rural Banyumas. Journal Of Rural Development. 2006;6(3):183-191.

19. Fabricius-Bjerre S, Jensen RB, Færch K, Larsen T, Mølgaard C, Michaelsen KF, Vaag A, Greisen G. Impact of birth weight and early infant weight gain on insulin resistance and associated cardiovascular risk factors in adolescence. PloS one. 2011;6(6):e20595.

doi:https://doi.org/10.1371/journal.pone.0 020595.

20. Trung TS, Phuong PTD. Bioactive compounds from by-products of shrimp processing industry in Vietnam. Journal of Food and Drug Analysis. 2012;20(1):194197.

21. Zhao J, Huang GR, Zhang MN, Chen WW, Jiang JX. Amino acid composition, molecular weight distribution and antioxidant stability of shrimp processing byproduct hydrolysate. Am J Food Technol. 2011;6(10):904-913. doi:http://dx.doi.org/10.3923/ajft.2011.90 4.913.

22. Mika A, Gołębiowski M, Skorkowski EF, Stepnowski P. Composition of fatty acids and sterols composition in brown shrimp Crangon crangon and herring Clupea harengus membras from the Baltic Sea. Oceanological and Hydrobiological Studies. 2012;41(2):57-64. doi:https://doi.org/10.2478/s13545-0120017-z.
23. Pongsilurang S. The Understanding and Usage of Pemali by the Toraja Society in Relation to Health Behavior. 2012.

24. Mulyani NS, AL Rahmad AH, Jannah R. Risk factors for blood cholesterol levels in outpatients with coronary heart disease in Meuraxa hospital. AcTion: Aceh Nutrition Journal. 2018;3(2):132-140. doi:10.30867/action.v3i2.113.

25. Dahlia S. The influence of Positive Deviance Approach towards Improvement of The Nutritional Status of Infants. Media Gizi Masyarakat Indonesia. 2012;2(1):15.

26. Rahmayana, Irviani AI, Dwi SD. The Relationship of Parenting The Mother with A Stunting Children Aged 24-59 Months in Coastal Region of Ashoka II Posyandu Kelurahan Tamalate Subdistrict Barombong Makassar City Year 2014. Vol. 4 No.2: Al Shihah Public Health Science Journal. 2014;4(2):424-436.

27. Riyadi H. Nutritional Status Assessment Method. Bogor: Fakultas Pertanian, Institut Pertanian Bogor; 2001.

28. Al-Rahmad AH, Fadillah I. Psychomotor of infant growth age 6-9 months based on exclusive breastfeeding. Aceh Nutrition Journal. 2016;1(2):99-104. doi:http://dx.doi.org/10.30867/action.v1i2 .18 .

29. Syarif E. The Integration of The Cultural Values of The Ethnic Bugis Makassar in The Learning Process s One of The Strategies of The Asean Economic Community is Facing (MEA). Jurnal Teori Praksis dan Pembelajaran IPS. 2016;1(1):13-21.

30. Indonesian Ministry of Health. Basic Health Research Results Report Indonesia Years 2018. Jakarta, Indonesia; 2018. 